\title{
EARTHQUAKE SOURCE AND GROUND MOTION CHARACTERISTICS IN EASTERN JAPAN DURING THE 2011 OFF THE PACIFIC COAST OF TOHOKU EARTHQUAKE
}

\author{
Hiroyuki GOTO ${ }^{1}$, Yoshiya HATA², Yasuko KUWATA ${ }^{3}$, Hidekazu YAMAMOTO ${ }^{4}$, \\ Hitoshi MORIKAWA $^{5}$ and Shunichi KATAOKA ${ }^{6}$ \\ ${ }^{1}$ Member of JSCE, Assistant Professor, Disaster Prevention Research Institute, Kyoto University \\ (Gokasho, Uji, Kyoto 611-0011, Japan) \\ E-mail: goto@catfish.dpri.kyoto-u.ac.jp \\ ${ }^{2}$ Member of JSCE, Assistant Professor, Dept. of Civil Eng., Osaka University \\ (2-1 Yamada-oka, Suita, Osaka 565-0871, Japan) \\ E-mail: hata@civil.eng.osaka-u.ac.jp \\ ${ }^{3}$ Member of JSCE, Associate Professor, Dept. of Civil Eng., Kobe University \\ (Rokkodai, Nada, Kobe 657-8501, Japan) \\ E-mail:kuwata@kobe-u.ac.jp \\ ${ }^{4}$ Associate Professor, Dept. of Civil and Environmental Eng., Iwate University \\ (4-3-5 Ueda, Morioka, 020-8551, Japan) \\ E-mail: yamamoto@iwate-u.ac.jp \\ ${ }^{5}$ Member of JSCE, Professor, Dept. of Built Environment, Tokyo Institute of Technology \\ (4259-G3-7 Nagatsuta, Midori-ku, Yokohama 226-8502, Japan) \\ E-mail: morika@enveng.titech.ac.jp \\ ${ }^{6}$ Member of JSCE, Associate Professor, Dept. of Earth and Environmental Sciences, Hirosaki University \\ (Bunkyo 3, Hirosaki, Aomori 036-8561, Japan) \\ E-mail:kataoka@cc.hirosaki-u.ac.jp
}

The 2011 off the Pacific coast of Tohoku earthquake brought severe damage caused not only by the tsunami but also by the ground motions. The present manuscript summarizes the source mechanism/process and the characteristics of ground motions around eastern Japan during the earthquake. For the last two years after the earthquake, many researchers have devoted their efforts to analyzing and discussing the source and ground motions. New findings from some recent works are also cited. We, furthermore, introduce characteristics of ground motions at some typical damaged sites, where no records of ground motions were obtained during the main shock, using time histories of after shocks.

Key Words : the 2011 off the Pacific coast of Tohoku earthquake, source mechanism, recorded data, earthquake ground motions, seismic intensity, PGA (peak ground acceleration)

\section{INTRODUCTION}

On March 11, 2011, a huge earthquake hit the eastern part of mainland Japan. The earthquake caused a huge tsunami that killed more than ten thousand people ${ }^{1)}$. Structures were also severely damaged over the area of eastern Japan by the tsunami, ground motions, liquefaction, and so on.

Strong ground motions during the earthquake were observed over almost the entire Japan. At least 18 stations observed peak horizontal accelerations of over $980 \mathrm{~cm} / \mathrm{s}^{2}=1 \mathrm{G}$, and three stations observed seismic intensities of 7 in the Japan Meteorological Agency (JMA) scale ${ }^{2), 3)}$ : MYG004 (K-NET Tsuki- date), TCGH16 (KiK-net Haga), and CCHG (SmallTitan Shichigo junior high school). However, the relationships between the damage and the large ground motions were not clear. Except for the damage by the tsunami, the structural damage was not much, though we found severe damage at some limited areas, such as Furukawa, Miyagi Prefecture, etc.

For the last two years after the huge and destructive 2011 earthquake, many researchers have devoted their efforts to analyzing its source mechanism, which includes the source process or rupture process, and characteristics of ground motions. This manuscript is a review of the last two-year results related to the source and ground motions. Furthermore, estimated 
ground motions were introduced at some typical damaged sites, where no records were available, using records of aftershocks.

It is, of course, very difficult to cover all the researches because of certain authors' limitations. Some details have been omitted to introduce as many works as possible. The authors expect that the readers will use the references. Although many references are written in Japanese, we believe that basic information can be gathered without much language-related problems.

\section{EARTHQUAKE SOURCE}

The earthquake, officially named "The 2011 off the Pacific coast of Tohoku Earthquake" by Japan Meteorological Agency (JMA), occurred at 14:46 (JST, GMT+9) on March 11, 2011. The hypocenter was located in the offshore region of the eastern part of mainland Japan, and the depth was $24 \mathrm{~km}$. The moment magnitude ( $\mathrm{Mw}$ ) was $9.0^{4)}$; it was the largest earthquake observed in Japan since 1900, and the 4th largest earthquake in the world since $1900{ }^{5)}$. The distribution of aftershocks occurring within 24 hours after the main shock almost covers the fault zone of the main shock as shown in Fig.1. It implies that dimensions of the fault zone were about $500 \mathrm{~km}$ in length along the coast line by about 200 $\mathrm{km}$ in width ${ }^{6}$. The centroid moment tensor (CMT) solutions estimated by $\mathrm{JMA}^{4)}$ and F-net organized by the National Research Institute for Earth Science and Disaster Prevention (NIED), are shown in Fig.1. They indicate that the mechanism was a reverse fault with a compressional axis in an almost east-to-west direction, which was estimated as $\mathrm{N} 103^{\circ} \mathrm{E}$ by JMA and $\mathrm{N} 110^{\circ} \mathrm{E}$ by NIED, respectively. The location of the seismic fault and the mechanism imply an inter-plate earthquake on the plate boundary between the North American plate and the Pacific plate.

The Headquarters for Earthquake Research Promotion (HERP) had warned of the occurrence of an earthquake in offshore Miyagi Prefecture with a probability of $99 \%$ and a scale of local magnitude defined by JMA (M JMA $) 7.5$ within 30 years. The event was expected to be similar to the Miyagi-oki earthquake (Mw 7.6) of 1978. However, the events corresponding to the Tohoku earthquake were not evaluated ${ }^{8)}$. The earthquake ruptured over several segments, which had been evaluated as independent earthquakes. After the earthquake, HERP revised the long-term probability; the same scale at that of the Tohoku earthquake was considered in the Tohoku region, and M8-9 class earthquakes were considered in

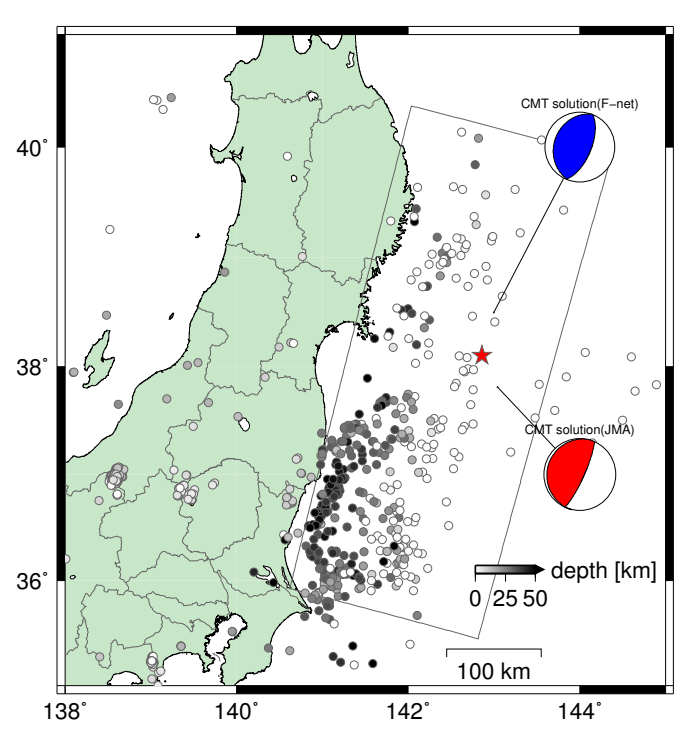

Fig.1 Aftershock distribution within 24 hours after the main shock, and CMT solutions estimated by JMA and F-net (NIED). The rectangle area indicates the seismic fault ${ }^{7)}$.

the Nankai trough region.

The earthquake caused severe tsunami damage along the coast line of the eastern part of mainland Japan ${ }^{9)}$. The large tsunami was generated by a large deformation of the seafloor. A geodetic observation very near the epicenter indicated $24-\mathrm{m}$ and $3-\mathrm{m}$ displacements in horizontal and vertical direction, respectively. They were obtained from the geodetic data before and after the earthquake ${ }^{10)}$. A differential bathymetry image across the trench also indicated 50$\mathrm{m}$ and 10-m displacements, respectively ${ }^{11)}$. The displacements were only available at the specific sites, although they imply that the seafloor deformation was at least in the order of $50 \mathrm{~m}$ in horizontal direction.

Slip distribution during the earthquake has been reported by many research groups in the field of earth science by using various types of data sets. The slip distributions were estimated from teleseismic waves ${ }^{12), 13)}$, geodetic data ${ }^{14), 15)}$, low-frequency components of regional ground motion data ${ }^{7), 16)}$, and tsunami data ${ }^{17), 18)}$. Some results were obtained from their combination ${ }^{19), 20)}$. Notice that the applied data sets correspond to static deformations and/or lowfrequency ground motions. More details of the slip distributions were described in another review article $^{5)}$. The maximum slip about $35-50 \mathrm{~m}$ was estimated, which was almost in the same order as the direct observation of the seafloor deformation ${ }^{10,11)}$. A region of the large slip was located on the shallower side of the seismic fault with the exception of a few models ${ }^{19)}$, and the non-zero slips were estimated at the trench. The deformations at the trench were 


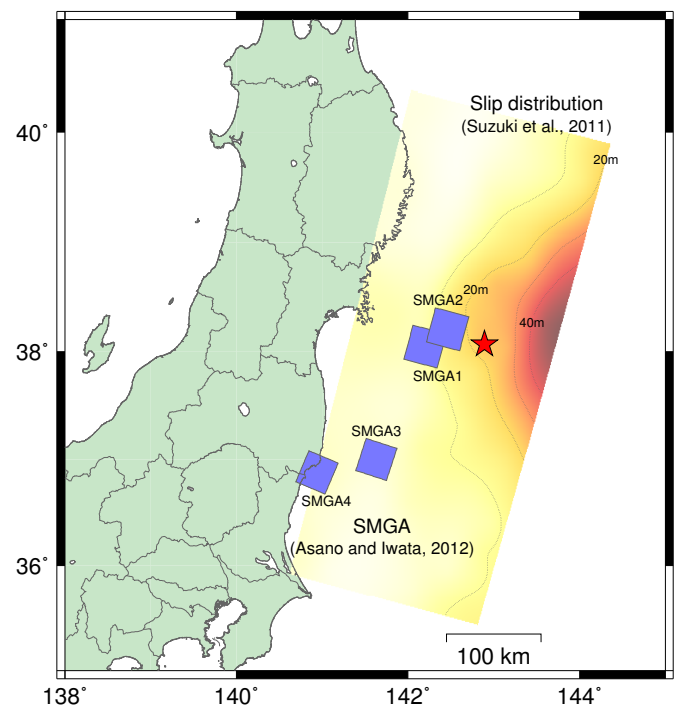

Fig.2 Slip distribution estimated from long period ground motions $^{7)}$ and SMGA locations ${ }^{22)}$. The star mark indicates the epicenter location.

also observed from the reflection image ${ }^{11)}$. They imply that the source rupture reached the seafloor during the earthquake.

Strong ground motions observed in the eastern part of the mainland incorporated the other important feature of the earthquake source: high-frequency radiations. Several articles emphasized the propagation of wave groups ${ }^{6,21), 22)}$. The first and second wave groups, with an interval of about 50 seconds, were mainly observed at the northern stations than in the epicenter. The wave groups were not clear at the southern stations, but a third wave group was mainly observed at the southern stations. This implies that the rupture process of the earthquake involved at least three significant events radiating high-frequency energy. The first two wave groups mainly affected the ground motions observed in Iwate and Miyagi Prefectures, while the third one affected the ground motions observed in Ibaraki and Tochigi Prefectures.

The corresponding source models were also investigated by several research groups. Highfrequency energy radiation areas were estimated by the back-projection method ${ }^{23), 24), 25)}$ and the envelope inversion $^{26)}$. More typical models characterized by strong motion generation areas (SMGAs) ${ }^{22), 27)}$ and by super asperities ${ }^{28)}$ were established. Please refer to the references for the concrete definitions of SMGA $^{22), 27)}$ and super asperity ${ }^{28)}$. The models emphasize the high-frequency aspects of the source rupture process higher than $0.1 \mathrm{~Hz}$. All the results imply that the high-frequency energies radiated from the deeper side of the seismic fault.

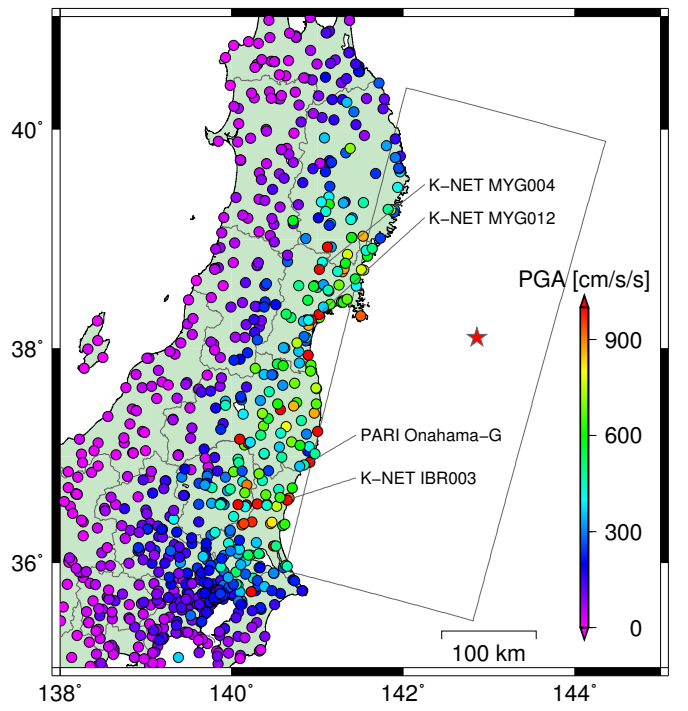

Fig.3 Distribution of peak ground accelerations (PGA) in horizontal components.

Fig.2 shows the slip distribution estimated by Suzuki et $a .^{7}{ }^{7}$, and the locations of SMGAs estimated by Asano and Iwata ${ }^{22)}$. The slip distribution corresponds to the low-frequency ground motions $(0.01-0.125 \mathrm{~Hz})$, and SMGAs correspond to the high-frequency ground motions $(0.1-10 \mathrm{~Hz})$. Obviously the locations of the large slips and the SMGAs do not overlap. The large slips are located at the eastern side, and SMGAs are located at the western side of the epicenter, which is indicated by a star mark in Fig.2. It implies that the locations of seismic wave radiation areas depend on the frequency band. The frequency dependency of the source models has been discussed in several articles ${ }^{29)}$-32).

Although there are various source models, we emphasize that the high-frequency radiations are relatively important in discussing the strong ground motion characteristics from an engineering point of view. The origins were closer than either the hypocenter or the large slip region, especially for Fukushima and Ibaraki Prefectures.

In addition to the results, physics-based approaches are required to understand the mechanism of the source rupture process. Several researches had attempted physics-based simulations during the Tohoku earthquake ${ }^{33)-37)}$. For example, the ground motions observed in Miyagi and Iwate Prefectures consisted of two major wave groups with an interval of about 50 seconds. The origins were estimated to be on the deeper side of the hypocenter, and located close to each other ${ }^{22), 27)}$, e.g., SMGA1 and SMGA2 in Fig.2. A time lag of about 50 seconds was required between the events. Goto et al. $^{36)}$ suggested that reflection 
Table1 Top 8 records of PGA in horizontal components

\begin{tabular}{cc}
\hline PGA $\left[\mathrm{cm} / \mathrm{s}^{2}\right]$ & Station \\
\hline 2765 & K-NET MYG004 \\
1970 & K-NET MYG012 \\
1913 & PARI Onahama-G \\
1844 & K-NET IBR003 \\
1807 & K-NET MYG013 \\
1614 & K-NET IBR013 \\
1425 & K-NET TCG009 \\
1425 & K-NET FKS016 \\
\hline
\end{tabular}

waves from the free surface affected the generation of the latter event based on the physics-based simulations.

\section{GROUND MOTIONS}

\section{(1) Overview}

Ground motions during the earthquake were observed by several seismic networks organized by NIED, JMA, Port and Airport Research Institute (PARI), Building Research Institute (BRI), National Institute for Land and Infrastructure Management (NILIM), and other organizations. These organizations have published their own reports on the data observed during the earthquake, including waveforms and even response spectra. The readers can refer to these reports and many of them can be accessed through the Internet ${ }^{38) \sim 42)}$.

Fig.3 shows the distributions of peak ground accelerations (PGA) in the horizontal components calculated from the available records of the ground motion. The PGAs in this figure were obtained from the combined time histories for two horizontal components.

The PGA values in Fig.3 do not simply attenuate from the east coast; they vary strongly along the coast line, similar to the seismic intensity distribution. Large PGAs were mainly observed in the regions of 1) Miyagi Prefecture, and 2) Tochigi and Ibaraki Prefectures, which are close to the locations of the SMGAs.

Table 1 lists the top 8 records of PGA in horizontal components. The largest PGA, $2765 \mathrm{~cm} / \mathrm{s}^{2}$, was observed at K-NET MYG004. It is almost three times larger than the gravitational acceleration. Even the second largest PGA observed at K-NET MYG012 is about twice larger than the gravitational acceleration. K-NET MYG004 and MYG012 are located in Miyagi Prefecture, while PARI Onahama-G and KNET IBR003 are located in Fukushima and Ibaraki Prefectures, respectively (see Fig.3). Large pSv values with periods in the range of 1.0-2.0s are concentrated in the northern part of Miyagi Prefecture ${ }^{6)}$.

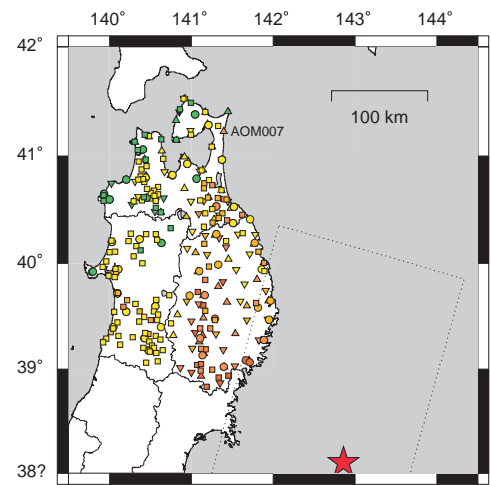

(a) JMA intensity

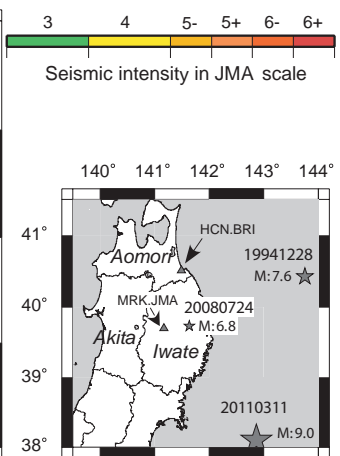

(b) Site location
Fig.4 Distribution of seismic intensity in JMA scale.

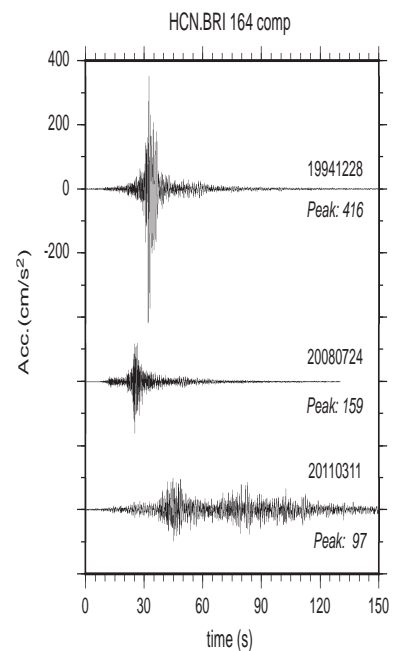

(a) HCN.BRI

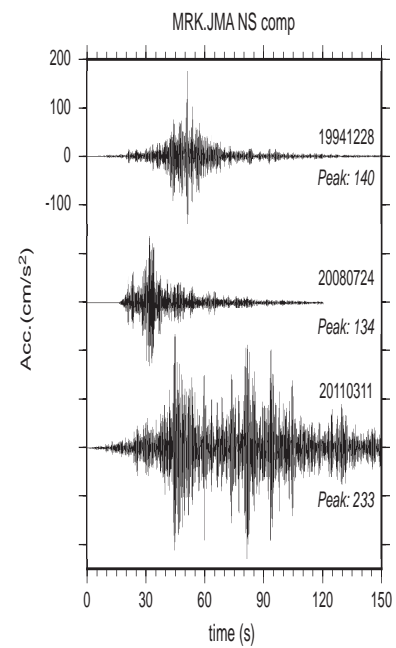

(b) MRK.JMA
Fig.5 Acceleration records obtained by the 1994, 2008, and 2011 events at Hachinohe city hall (HCN.BRI) and Morioka JMA observatory (MRK.JMA).

\section{(2) Northern Tohoku area}

Ground motion characteristics around northern Tohoku region are described in this section. Northern Tohoku region consists of Iwate, Akita, and Aomori Prefectures, where they are located south-east, southwest, and north of the area, respectively, as shown in Fig.4(b). As described previously, ground motions in this region were not so large compared to those in the southern area. Thus, severe damage induced by ground motion was not found except for the southern part of Iwate Prefecture ${ }^{43)}$.

Fig.4(a) shows the distribution of seismic intensities in this region. The figure illustrates the values of seismic intensities provided by JMA and values calculated from the records of K-NET and KiK-net. The highest value of intensity in this figure is $6^{-}$. Stations, where $6^{-}$intensity were recorded, are located around the southern boundary of Iwate Prefecture and the southern part along Kitakami-gawa river. The north- 


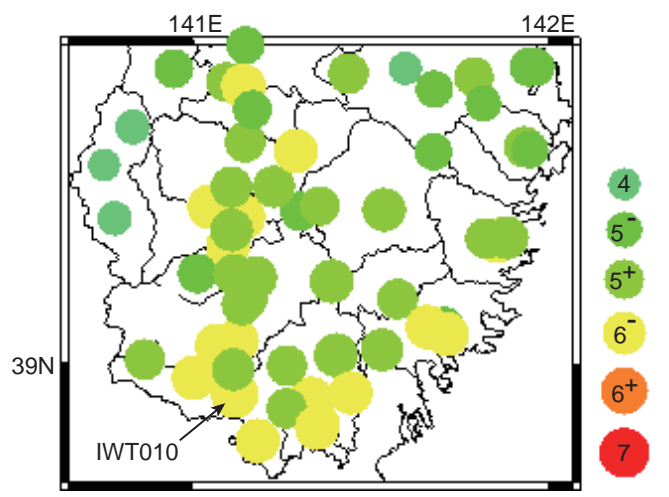

Fig.6 Distribution of seismic intensities of the 2011 off the Pacific coast of Tohoku earthquake around the southern area of Iwate. The numbers in the legend denote seismic intensity in JMA scale.

ern limit of the area with $6^{-}$intensity is about 40 degrees latitude. On the other hand, there are few sites with $6^{-}$intensity along the eastern coast line, even though the fault plane is located beneath the coast line. Detailed characteristics of ground motions are discussed in the following section for the southern area of Iwate Prefecture.

In Aomori and Akita Prefectures, the highest intensity is $5^{+}$. Most stations with intensity of $5^{+}$are located in the south-eastern area of the Aomori Prefecture except for a K-NET station AOM007 (Minamidori), where very stiff layer is covered by very soft peat layer. It has been noted that larger ground motions caused by recent earthquakes have been recorded at the stations where intensity of $5^{+}$was observed during the 2011 event, than at their surrounding stations ${ }^{44)}$.

The northern Tohoku area has been hit by many earthquakes in the last few decades. Fig.5 compares the 2011 acceleration records with those of the 1994 and 2008 events at two typical sites: Hachinohe city hall (HCN.BRI) of Aomori and JMA observatory at Morioka (MRK.JMA) of Iwate. The site locations and epicenters of the earthquakes are shown in Fig.4(b). The two events were the 1994 SanrikuHaruka-Oki earthquake, which occurred in the eastern off shore on December 28, 1994, and the 2008 earthquake, which occurred in the northern coastal area of Iwate on July 24, 2008.

These two events brought some damage to Hachinohe city. From Fig.5(a), it is observed that the 2011 event has smaller amplitude and longer duration than the other two events. The seismic intensity of the 2011 event is also smaller than others. This explains why there was less damage around Hachinohe city during the 2011 event.

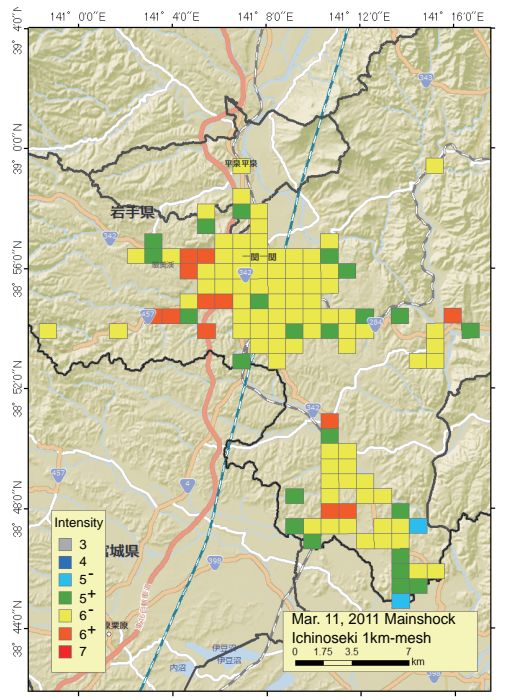

Fig.7 Distribution of questionnaire seismic intensities in Ichinoseki City, Iwate Prefecture. The seismic intensity is averaged for every $1-\mathrm{km}$ mesh.
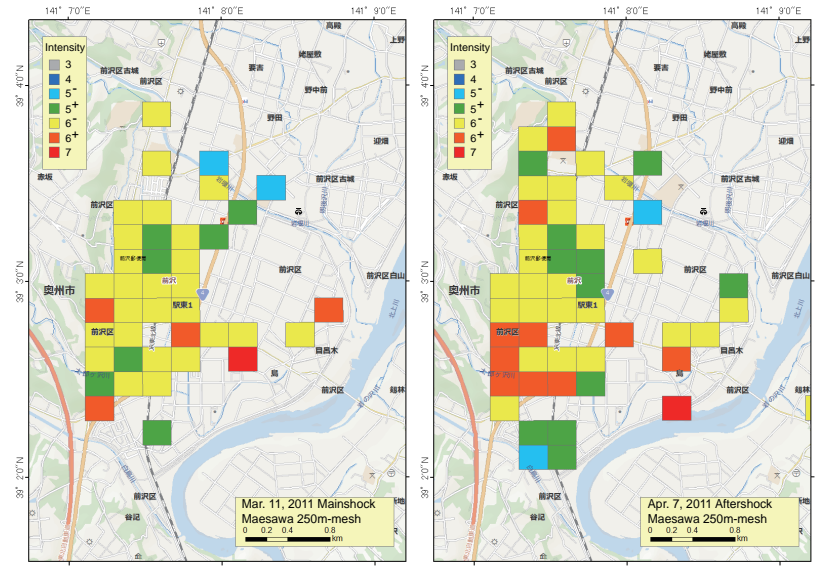

Fig.8 Distribution of questionnaire seismic intensities for the mainshock (left panel) and the aftershock (right panel) in the central area of Maesawa District of Oshu City, Iwate Prefecture. The seismic intensity was averaged for every 250-m mesh.

On the other hand, the 2011 event recorded the largest value of JMA intensity at MRK.JMA in its history as shown in Fig.5(b). The peak ground acceleration, however, is only about $200 \mathrm{~cm} / \mathrm{s}^{2}$. This may not bring any severe damage to well-designed structures in Japan.

\section{(3) Southern area of Iwate Prefecture}

In this section, strong motion characteristics are described around the southern area of Iwate Prefecture, Northern Honshu, Japan by the 2011 off the Pacific coast of Tohoku earthquake. We discuss the seismic records observed at the stations of the K-NET and KiK-net strong motion networks operated by NIED. Only records with epicentral distances of less than $250 \mathrm{~km}$ were analyzed. 
Fig.6 shows the distribution of seismic intensities reported by JMA. In this area, seismic intensities range from 4 to $6^{-}$. It is observed that the stations with $6^{-}$are mainly located in the marginal area of southern Iwate. PGA values are 998 and $852 \mathrm{~cm} / \mathrm{s}^{2}$ at the IWT010 station (K-NET Ichinoseki) for NS and EW components, respectively. At the same station, the maximum values of peak ground velocity (PGV) are also obtained: 49 and $36 \mathrm{~cm} / \mathrm{s}$ for NS and EW components, respectively. $\mathrm{PGV}$ is relatively small compared to the large value of PGA which is almost $1 \mathrm{G}$. This suggests that the strong motion includes richer components with high frequencies than low frequencies. Except for the IWT010 station, PGA and PGV are not so large.

Serious damage has been brought to the coastal area by the tremendous tsunami, though damage caused by the ground motions of the main shock was not so severe, because the ground motions were not so large. To confirm this and discuss the detailed distribution of ground motions, seismic intensity mapping was carried out by high-density questionnaire survey at specific cities in southern Iwate ${ }^{45), 46)}$.

Fig.7 shows the distribution of questionnaire seismic intensities for the main shock in Ichinoseki City, Iwate Prefecture. The seismic intensities are averaged for every $1-\mathrm{km}$ mesh. The figure shows that the distribution of seismic intensities was inhomogeneous in the area. Fig.8 shows the distribution of questionnaire seismic intensities for the main shock and the aftershock in the central area of Maesawa District of Oshu City, Iwate Prefecture. The seismic intensities are averaged for every 250-m mesh. Damage in residential structures was mainly due to the aftershocks rather than by the main shock. The figure shows that the seismic intensities of the aftershock are larger than those of the main shock at some meshes.

\section{(4) Miyagi and Yamagata Prefectures}

In Yamagata Prefecture, the ground motions were not so large, thus very few notable ground motions and damage were found. In fact, the maximum intensity reported by JMA was $5^{+}$and the PGAs observed by NIED were less than $300 \mathrm{~cm} / \mathrm{s}^{2}$. The maximum value of PGAs recorded by NIED in Yamagata Prefecture was $263 \mathrm{~cm} / \mathrm{s}^{2}$ at Kaminoyama (KiK-net YMTH04) and the second maximum was $251 \mathrm{~cm} / \mathrm{s}^{2}$ at Obanazawa (K-NET YMT006). The seismic intensities in JMA scale, which were calculated from time histories observed by NIED were $5^{+}$or less than $5^{+}$.

There were few seismic observation stations around the border area between Yamagata and Miyagi Prefectures, which is a rugged and mountainous district

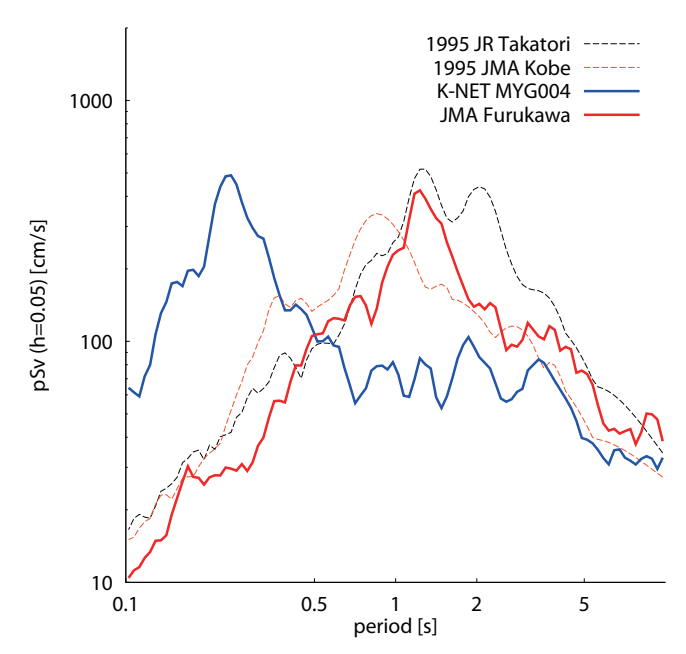

Fig.9 Pseudo-velocity response spectra $(h=0.05)$ of KNET MYG004 and JMA Furukawa, compared to JMA Kobe and JR Takatori records during the 1995 Kobe earthquake.

including Zao Mountain Range. Thus, it is very difficult to know the detailed distribution of the ground motions from the observed data. At least, we can say that the differences were not small between the western and eastern sides of the border area. These differences may suggest the complexities of deep ground structure under the northern part of mainland Japan (Honshu).

Seismic intensities of $6^{+}$and 7 in the JMA scale were recorded at more than 10 sites in Miyagi Prefecture. There were dense observation networks for strong motion in Sendai City and detailed discussions on the characteristics of ground motions are available $^{47), 48)}$. The geological settings in Sendai can be divided into two areas: a plateau in the northwestern area and lowland in the south-eastern area, with the Nagamachi-Rifu fault as the boundary. Large ground motions were observed around the eastern part of the fault and the northern area of downtown. The peaks of pseudo-velocity spectra are found around 0.5 to 1.0 second for many of the records. Ohno et al. ${ }^{47)}$ estimated ground motions during the mainshock around Sendai area, and pointed out that the area with large ground motion depended on its period: 0.2-second motions predominate in the northwestern area of the fault, 1-second motions in eastern area of the fault, and 3-second motions in the southern area of downtown.

Typical properties of ground motions can be summarized from the records at Tsukidate and Furukawa. Hereafter, we introduce the characteristics of ground motions at these areas. The Tsukidate area is located in Kurihara City, Miyagi Prefecture, which is about 


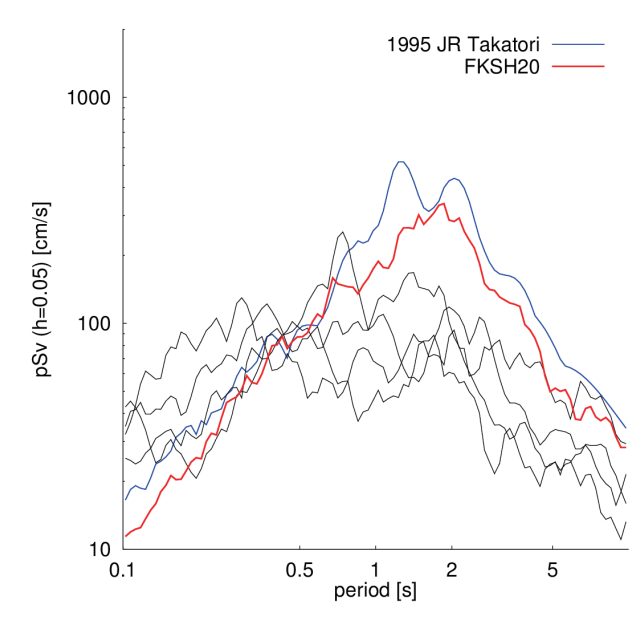

Fig.10 Pseudo-velocity response spectra observed at some sites in Fukushima. The red line represents the record at FKSH20, blue line at severely damaged area during the 1995 Kobe earthquake, and black lines at FKS001, FKS005, FKS007, and FKS010. Damping coefficient is 0.05 .

$60 \mathrm{~km}$ north of Sendai City. There is one seismic station, K-NET MYG004 (Tsukidate), which observed the largest PGA of $2765 \mathrm{~cm} / \mathrm{s}^{2}$ and a seismic intensity of 6.6 in the JMA scale. However, little damage was reported in this area.

Fig.9 shows the pseudo-velocity response spectra of the MYG004 and JMA Furukawa records. Each line shows the component of a specific direction with the largest peak at each station. The damping coefficient is set to be 0.05 . The response spectra are compared with the JMA Kobe and JR Takatori records taken during the 1995 Kobe earthquake. The Takatori record was observed in the damage belt, the area with a seismic intensity of 7 in the old JMA scale. The pSv values at K-NET MYG004 exceeded the JR Takatori records at periods shorter than $0.5 \mathrm{~s}$, whereas those in the range of 1.0-2.0s were almost $1 / 4$ of those of the JR Takatori records. This means that the frequency content of the records with the large PGAs was not similar to that of the JR Takatori records and that the large PGA did not contribute to the damage around the Tsukidate area.

On the other hand, during the 2011 Off the Pacific Coast of Tohoku Earthquake, severe structural damage occurred in the Furukawa District of Osaki City, which is located at approximately $35 \mathrm{~km}$ north of Sendai City, and $20 \mathrm{~km}$ south of Tsukidate. The Furukawa station of JR Tohoku Shinkansen (Bullet Train) and JR Riku-u-tosen are located in the center of the district. There are four seismic stations in the area, K-NET MYG006 (Furukawa), JMA Furukawa, Furukawa Gas, and NILIM (National Insti-

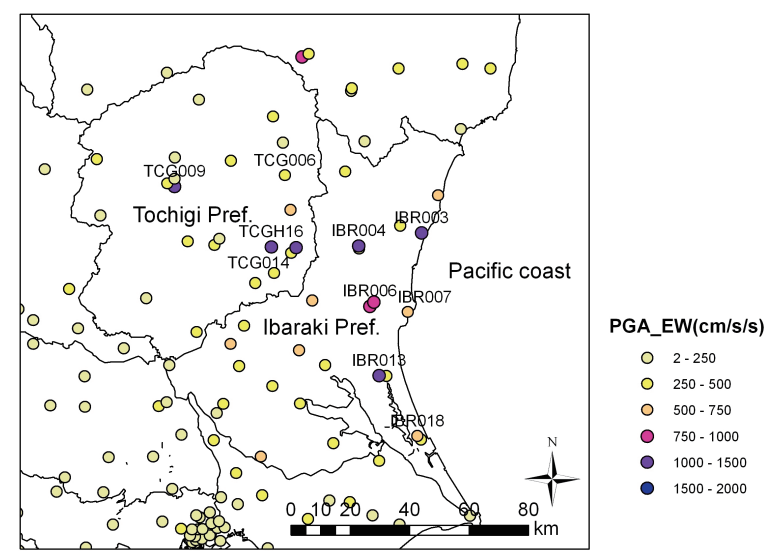

Fig.11 Map showing the location of K-NET and KiK-net stations with PGA.

tute for Land and Infrastructure Management) Furukawa. Unfortunately, however, the Furukawa Gas station did not record the time histories of the main shock $^{49)}$. The K-NET MYG006, JMA Furukawa, and NILIM Furukawa stations recorded PGAs of $583 \mathrm{~cm} / \mathrm{s}^{2}, 568 \mathrm{~cm} / \mathrm{s}^{2}$, and $483 \mathrm{~cm} / \mathrm{s}^{2}$, respectively, and the corresponding seismic intensities in the JMA scale were 6.1, 6.2, and 6.1.

The Furukawa district is located on the Osaki plain, which is covered by Holocene sediments ${ }^{50)}$, and the terrain is almost flat with elevations from 17 to $21 \mathrm{~m}$. The soil properties at some sites in downtown are available ${ }^{51)}$.

Damage distribution based on the reconnaissance immediately after the main shock had been reported ${ }^{6}$. Damage due to the liquefaction was observed in the western area of the JR Furukawa station, and damage due to the ground motion was observed in the area neighboring the liquefaction area.

The damage level was different between the areas within several hundred meters from the K-NET MYG006 and JMA Furukawa stations, which are approximately $1 \mathrm{~km}$ away from each other. The severe damage was concentrated within the area approximately $1 \times 1 \mathrm{~km}^{2}$ including the JMA station. From Figure 9, pSv observed in downtown Furukawa show similar shapes, especially in the period range of 1-2s, to those of the Kobe earthquake, which caused destructive damage to structures: this is not the case for the spectra of the MYG006 record. It is noted that the JMA Furukawa station is closer to the severely damaged area than the MYG006 one. This suggests that the power of the ground motions around 1s plays an important role in the structural damage and that the spatial variation of the ground motions may be critical for the damage.

To confirm this, Goto et al. ${ }^{51)}$ installed many 


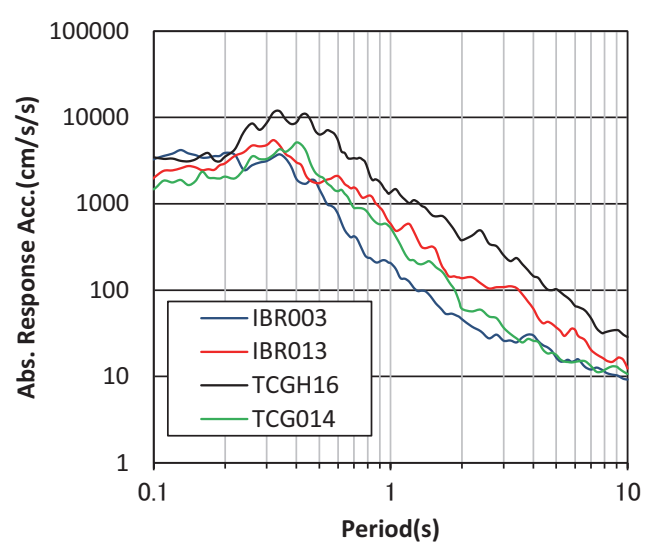

Fig.12 Response acceleration spectra of records with peak ground acceleration more than $1 \mathrm{G}$.

sensors into downtown Furukawa, and estimated ground structure using some geological survey techniques ${ }^{52), 53)}$. Many records of aftershocks and estimated ground structure suggest clear correlations between damage and spatial variations in ground motions.

\section{(5) Fukushima Prefecture}

Some stations recorded more than $1 \mathrm{G}$ of PGA in Fukushima Prefecture, and two seismic stations in Fukushima Prefecture are listed in Table 1, which shows the top 8 records of PGA in horizontal components. These two sites are located in the southern area of Fukushima Prefecture. Onahama (PARI Onahama$\mathrm{G})$ is located in the maritime area, which is close to the source region and Shirakawa (K-NET FKS016) in the inland area. Large PGAs were also recorded around these two sites, both maritime and inland areas. In the maritime area, remarkably large values of PGAs were observed at Hirono (K-NET FKS010) and Ohkuma (K-NET FKS007). PGAs were also larger than $1000 \mathrm{~cm} / \mathrm{s}^{2}$ around Koriyama, which is located in the inland area. These large values of PGAs seem to correspond to the location of strong motion generation areas (SMGAs), discussed in Fig.2.

The pseudo-velocity response spectra at many stations in Fukushima predominate in period range shorter than 0.5 seconds; however, a few stations show particular spectral peak longer than 1 second as shown in Fig.10. In this figure, pseudo-velocity response spectra are drawn at some sites in Fukushima. The lines in Fig.10 are obtained by the same procedure as described for Fig.9. Only KiK-net FKSH20 (Namie) has a shape closer to the spectrum observed in the severely damaged area during the 1995 Kobe earthquake, and many damaged wooden structures

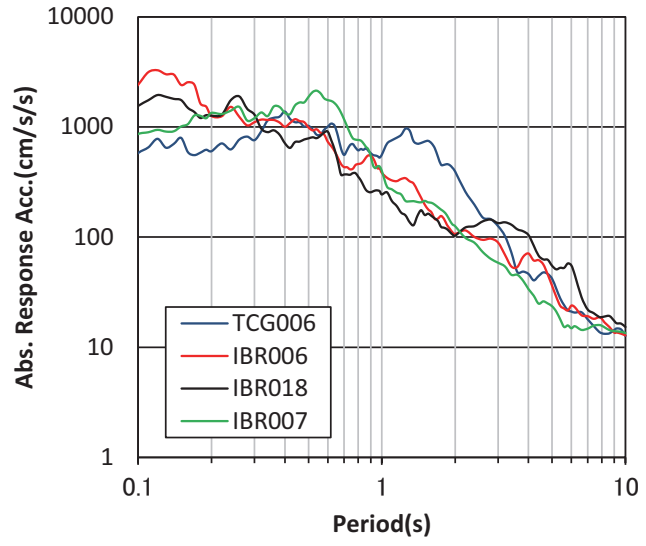

Fig.13 Response acceleration spectra of records near damage sites or records with predominant period around 1 second.

were found around the Namie station.

Furthermore, Nakamura et al. ${ }^{54)}$ estimated the detailed distribution of seismic intensities around Koriyama and Sukagawa using questionnaire survey. They divided the target area into small areas with different postal (zip) codes and accepted the small areas with at least three responses to the questionnaire. The seismic intensities were provided by the values averaged over each accepted area. The accepted areas covered the downtown and estimated distribution of the seismic intensities can be used with statistical meaning to discuss the relationships between damage and ground motions.

Although seismic intensities officially reported by JMA in Koriyama, were mainly $6^{-}$or $6^{+}$, the area with $6^{+}$was not so large. On the other hand, intensities of $6^{-}$or $6^{+}$were also reported in Sukagawa, though the results of the questionnaire show that the intensities varied from $5^{-}$to 7 and that the area with $6^{+}$was relatively larger than the $6^{+}$area around Koriyama.

\section{(6) Ibaraki and Tochigi Prefectures}

Ibaraki and Tochigi are neighboring prefectures in the southern part of Fukushima Prefecture, Tohoku region. As discussed in Section 2, the strong ground motions observed in Ibaraki and its southward area were induced by contribution of the third wave group out of the three main wave groups.

Among the 20 of K-NET and KiK-net stations of NIED, most PGAs exceeding $1 \mathrm{G}^{55}$ were observed in Ibaraki and Tochigi Prefectures, such as 1,845 $\mathrm{cm} / \mathrm{s}^{2}$ at K-NET Hitachi (IBR003), $1,762 \mathrm{~cm} / \mathrm{s}^{2}$ at K-NET Hokota (IBR013), 1,305 cm/ $\mathrm{s}^{2}$ at KiK-net Haga (TCGH16) and $1291 \mathrm{~cm} / \mathrm{s}^{2}$ at K-NET Motegi (TCG014) as shown in Fig.11. In the response accel- 
eration spectra $(h=0.05)$ of these records shown in Fig.12, predominant periods shorter than 0.5 second are remarkable. These high acceleration records have similarly large amplitudes within a short period.

Strong ground-motion records in the near-source region provide detailed information about the shorterperiod rupture process during the earthquakes. Irikura and Kurahashi ${ }^{56)}$ found that five SMGAs, with large slip velocity or high stress drop, distributed across the entire rupture area of the earthquake. One of SMGA close to Ibaraki prefecture appeared to have high acceleration. Nozu et al. ${ }^{57)}$ also showed super asperity near the above SMGA.

As for the relation of ground motion and damage to civil works, the strong ground-motion at the damage site of Joban expressway embankment, bearing of Nakagawa aqueduct, rubber bearings of Asahi viaduct and Shin-Nakagawa bridge, falling down of Rokko bridge were estimated by Hata et al. ${ }^{58)-61)}$. The acceleration response spectrum of estimated ground motions also has predominant period shorter than 1 second, similar to nearby seismometer stations of KNET Mito (IBR006), K-NET Nakaminato (IBR007) and K-NET Kashima (IBR018) as shown in Fig.13. In Ibaraki Prefecture, except for wooden houses, not much damage to buildings and residential houses due to ground shaking was recorded. Incidentally, the predominant period shorter than 1 second might cause damage to nonstructural components such as falling down of ceilings and exterior walls and breakage of window ${ }^{62)}$.

The ground motion observed at K-NET Ogawa (TCG006) had predominant period around 1 second different from the other stations in Ibaraki and Tochigi Prefectures. The ground motion of the strongest aftershock also had similar predominant period. Tombs near the station turned over and roofs of houses fell down ${ }^{63)}$.

The stations described herein are located on relatively stiff ground and liquefaction was not observed at their vicinity throughout the field investigation. Along the month of the Tone River and near the Pacific coast, severe liquefaction was induced by ground shaking.

\section{STRONG MOTION ESTIMATION AT DAMAGE SITES}

To analyze the damage mechanism by ground motions, it is very important to estimate the strong ground motions at the damage sites ${ }^{64)}$. Thus, we estimated the strong motions at the sites of interest as

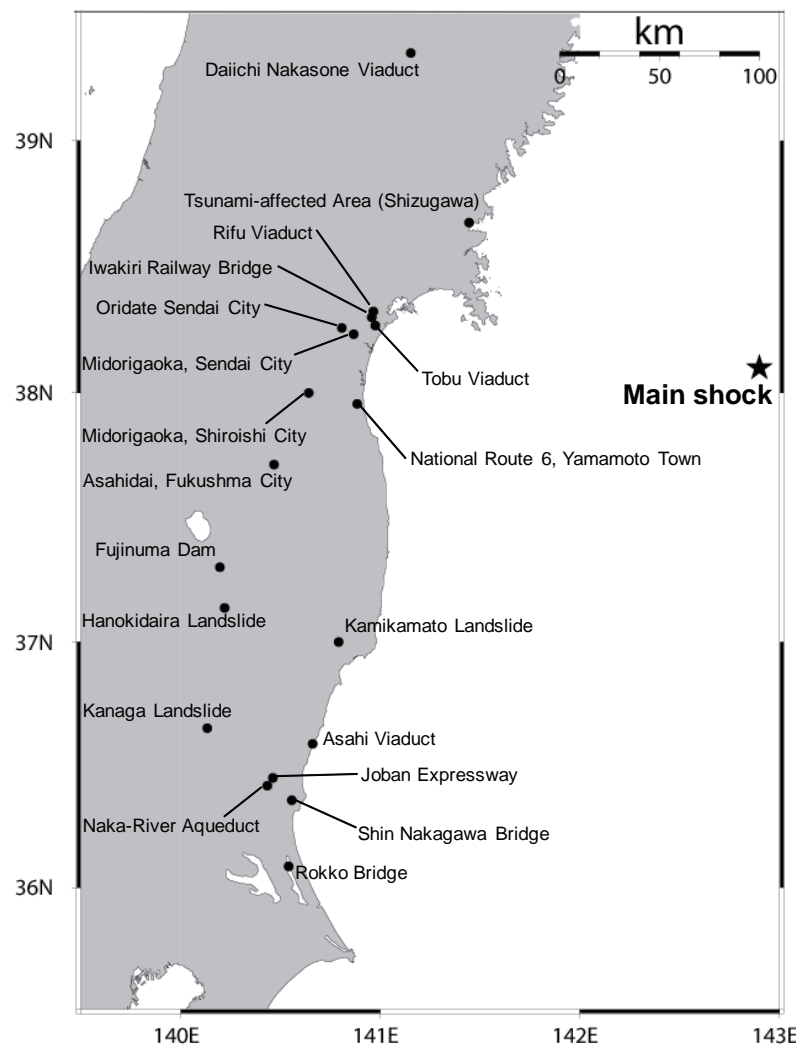

Fig.14 Location of target sites to estimate strong motions.

shown in Fig.14 during the 2011 main shock based on the records of temporal observation for aftershocks. The estimation results are summarized for each classification of civil structure, such as slope and so on.

\section{(1) Bridges}

The 2011 main shock brought serious damage to some railway bridges including the elevated bridges of the Tohoku Shinkansen (Daiichi Nakasone Viaduct) in Iwate Prefecture ${ }^{65)}$, Iwakiri Railway Bridge, Sendai City, Miyagi Prefecture ${ }^{66)}$, etc. Although most expressway bridges designed using post1990 code were not damaged by ground motion, rubber bearings were severely damaged at bridges designed using post-1995 code $^{67)}$ : e.g., Rifu Viaduct, Tobu Viaduct, Asahi Viaduct, Shin Nakagawa Bridge. Furthermore, Rokko Bridge of National Route 354, Ibaraki Prefecture lost two piers and three spans ${ }^{68)}$.

Hata $e$ al. estimated ground motions at the site where significant damage was found ${ }^{69), 70), 58), 59)}$. To obtain appropriate estimations, they applied various techniques such as extended site-effect substitution method $^{71)}$, a super asperity model ${ }^{28)}$ considering empirical site amplification and phase effects, observation of aftershocks, comparison between estimated waveforms and observed ones, and so on. 


\section{(2) Aqueduct}

The Naka River Aqueduct in Ibaraki Prefecture also suffered significant damage including pipe dropout in expansion joints ${ }^{72)}$. Hata et $a l .{ }^{61)}$ carried out observation of aftershocks using dense array at the damage site and carefully estimated strong motions. On the basis of observed data, differences in site effects between the landside area and the riverside area were presented. The seismic waveforms were also estimated at permanent stations for observation of strong motions using the site-effect substitution method ${ }^{71)}$ and they agreed well with the observed ones. After the confirming the validity of the analysis technique, the method was applied to estimate strong ground motions at the damage site.

\section{(3) Residential area and landslides}

Landslides or slope failure in residential areas were found at some places such as Oritate ${ }^{73)}$ and Midorigaoka $^{74)}$ in Sendai City, Midorigaoka ${ }^{75)}$ in Shiroishi City, Asahidai ${ }^{76)}$ in Fukushima City, and so on. Hata et al. estimated the strong motions at these sites $^{77)-80)}$ on the basis of the site-effect substitution method $^{71)}$.

Many and/or large-scale landslides were also found around Hanokidaira ${ }^{81)}$ in Shirakawa City, Kamikamato $^{82)}$ in Iwaki City, and Kanaga ${ }^{83)}$ in Nasukarasuyama City, etc. Hata et al. also estimated the seismic motions at the sites ${ }^{84), 85), 86)}$.

\section{(4) Road embankment and fill dam}

Slope failure occurred in an embankment of the Joban expressway during the 2011 main shock and its largest aftershock ${ }^{87)}$. Much serious damage also occurred in embankments of National Route 6 in Yamamoto, Miyagi Prefecture ${ }^{88)}$. The strong motions were estimated at the sites ${ }^{60), 89)}$.

Fuijinuma Dam in Fukushima Prefecture was damaged and completely lost soil embankment ${ }^{90)}$. Hata et al. ${ }^{91)}$ applied the site-effect substitution method ${ }^{71)}$ to estimate the ground motions at the site. The same method was also applied to estimate ground motions at strong motion stations surrounding the dam site. The estimated ground motions at the dam site were significantly different from those observed at a nearby strong motion station in terms of phase characteristics.

\section{(5) Tsunami-affected area}

Enormous damage occurred to the disaster countermeasures office, the river bridges and the fishery port facilities in Shizugawa, Minamisanriku due to the 2011 main shock ${ }^{92)}$. To evaluate the performance of structures before the tsunami, it is necessary to estimate strong motions in Shizugawa Area with sufficient accuracy, taking into account site effects. Seismic waveform in Shizugawa Area was estimated based on a super asperity model ${ }^{57)}$ considering empirical site amplification and phase effects ${ }^{93)}$. The estimated seismic waveform will be useful in the detailed study of seismic performance of structures before the tsunami.

\section{REMARKS}

In this study, we introduce the recent results on the source mechanism/process and ground motions for the 2011 off the Pacific coast of Tohoku earthquake. Furthermore, we also introduce estimated ground motions at some sites where the ground motions of the main shock are not available. We hope this manuscript helps readers in reviewing the last two-year researches on the source and ground motions.

ACKNOWLEDGMENTS: The digital data of seismograms were obtained from the seismic networks of K-NET and KiK-net (http://www.kyoshin. bosai.go.jp/kyoshin/). The authors would like to thank the National Research Institute for Earth Science and Disaster Prevention (NIED), Japan, for providing the KiK-net and K-NET waveform data. Furthermore, we are also deeply grateful for the release of strong motion data by many organizations, including the National Institute for Land and Infrastructure Management (NILIM), Japan Meteorological Agency (JMA), Port and Airport Research Institute (PARI), Building Research Institute (BRI). Some figures were made using Generic Mapping Tools ${ }^{94)}$.

\section{REFERENCES}

1) Ministry of Land, Infrastructure, Transport and Tourism: White Paper on Land, Infrastructure, Transport and Tourism in Japan, 2011, http: //www . mlit.go.jp/english/white-paper/2011.pdf, 2011 (access: Aug. 25, 2013).

2) Kunugi, T., Aoi, S., Suzuki, W., Nakamura, H., Morikawa, N. and Fujiwara, H.: Strong Motions of the 2011 Tohoku-oki earthquake, Research Reporton the 2011 Great East Japan Earthquake Disaster, $\mathrm{Na}$ tional Disaster Research Report, National Research Institute for Earth Science and Disaster Prevention, No.48, pp.63-72, 2012 (in Japanese with English abstract and captions).

3) Kamiyama, M.: Strong motion records by SmallTitan during 2011 off the Pacific coast of Tohoku earthquake, http://www.st.hirosaki-u.ac.jp/ 
kataoka/TohokuEQ/KamiyamaSmallTitan_01. pdf, 2011 (access: Aug. 25, 2013).

4) Hirose, F., Miyaoka, K., Hayashimoto, N., Yamazaki, T. and Nakamura, M.: Outline of the 2011 off the Pacific coast of Tohoku earthquake (Mw9.0) -seismicity: foreshocks, mainshock, aftershocks, and induced activity-, Earth Planets Space, Vol.63, pp.513-518, 2011.

5) Tajima, F., Mori, J. and Kennett, B.L.N.: A review of the 2011 Tohoku-Oki earthquake (Mw9.0): Largescale rupture across heterogeneous plate coupling, Tectonophysics, Vol.586, pp.15-34, 2013.

6) Goto, H. and Morikawa, H.: Ground motion characteristics during the 2011 off the Pacific coast of Tohoku earthquake, Soils and Foundations, Vol.52, pp.769-779, 2012.

7) Suzuki, W., Aoi, S., Sekiguchi, H. and Kunugi, T.: Rupture process of the 2011 Tohoku-Oki mega-thrust earthquake (M9.0) inverted from strong-motion data, Geophys. Res. Lett., Vol.38, L00G16, 2011.

8) Stein, S., Geller, R.J. and Liu, M.: Why earthquake hazard maps often fail and what to do about it, Tectonophysics, Vol.562-563, pp.1-25, 2012.

9) Mori, N., Takahashi, T., Yasuda, T. and Yanagisawa, H.: Survey of 2011 Tohoku earthquake tsunami inundation and run-up, Geophys. Res. Lett., Vol.38, L00G14, 2011.

10) Sato, M., Ishikawa, T., Ujihara, N., Yoshida, S., Fujita, M., Mochizuki, M. and Asada, A.: Displacement above the hypocenter of the 2011 Tohoku-oki earthquake, Science, Vol.332, p.1395, 2011.

11) Kodaira, S., No, T., Nakamura, Y., Fujiwara, T., Kaiho, Y., Miura, S., Takahashi, N., Kaneda, Y. and Taira, A.: Coseismic fault rupture at the trench axis during the 2011 Tohoku-oki earthquake, Nature Geoscience, Vol.5, pp.646-650, 2012.

12) Yagi, Y. and Fukahata, Y.: Rupture process of the 2011 Tohoku-Oki earthquake and absolute elastic strain release, Geophys. Res. Lett., Vol.38, L19307, 2011.

13) Yoshida, Y., Ueno, H., Muto, D. and Aoki, S.: Source process of the 2011 off the Pacific coast of Tohoku earthquake with the combination of teleseismic and strong motion data, Earth Planets Space, Vol.63, pp.565-569, 2011.

14) Miyazaki, S., McGuire, J.J. and Segall, P.: Seismic and aseismic fault slip before and during the 2011 off the Pacific coast of Tohoku Earthquake, Earth Planets Space, Vol.63, pp.637-642, 2011.

15) Nishimura, T., Munetake, H. and Yarai, H.: The 2011 off the Pacific coast of Tohoku earthquake and its aftershocks observed by GEONET, Earth Planets Space, Vol.63, pp.631-636, 2011.

16) Yoshida, K., Miyakoshi, K. and Irikura, K.: Source process of the 2011 off the Pacific coast of Tohoku earthquake with the combination of teleseismic and strong motion data, Earth Planets Space, Vol.63, pp.577-582, 2011.

17) Fujii, Y., Satake, K., Sakai, S., Shinohara, M. and Kanazawa, T.: Tsunami source of the 2011 off the Pacific coast of Tohoku earthquake, Earth Planets Space, Vol.63, pp.815-820, 2011.

18) Saito, T., Ito, Y., Inazu, D. and Hino, R.: Tsunami source of the 2011 Tohoku Oki earthquake, Japan: inversion analysis based on dispersive tsunami simulations, Geophys. Res. Lett., Vol.38, L00G19, 2011.

19) Koketsu, K., Yokota, Y., Nishimura, N., Yagi, Y., Miyazaki, S., Satake, K., Fujii, Y., Miyake, H., Sakai, S., Yamanaka, Y. and Okada, T.: A unified source model for the 2011 Tohoku earthquake, Earth and Planetary Science Letters, Vol.310, pp.480-487, 2011.

20) Kubo, H. and Kakehi, Y.: Source process of the 2011 Tohoku earthquake estimated from the joint inversion of teleseismic body waves and geodetic data including seafloor observation data: source model with enhanced reliability by using objectively determined inversion settings, Bull. Seism. Soc. Am., Vol.103, pp.1195-1220, 2013.

21) Furumura, T., Takemura, S., Noguchi, S., Takemoto, T., Maeda, T., Iwaki, K. and Padhy, S.: Strong ground motions from the 2011 off-the-PacificCoast-of-Tohoku, Japan (Mw=9.0) earthquake obtained from a dense nationwide seismic network, Landslide, Vol.8, pp.333-338, 2011.

22) Asano, K. and Iwata, T.: Source model for strong ground motion generation in the frequency range 0.1-10Hz during the 2011 Tohoku earthquake, Earth Planets Space, Vol.64, pp.1111-1123, 2012.

23) Ishii, M.: High-frequency rupture properties of the Mw9.0 off the Pacific coast of Tohoku Earthquake, Earth Planets Space, Vol.63, pp.609-614, 2011.

24) Wang, D. and Mori, J.: Rupture process of the 2011 off the Pacific coast of Tohoku Earthquake (Mw 9.0) as imaged with back-projection of teleseismic P-waves, Earth Planets Space, Vol.63, pp.603-607, 2011.

25) Zhang, H., Ge, Z. and Ding, L.: Three sub-events composing the 2011 off the Pacific coast of Tohoku Earthquake (Mw9.0) inferred from rupture imaging by back-projecting teleseismic P-waves, Earth Planets Space, Vol.63, pp.595-598, 2011.

26) Nakahara, H.: Envelope inversion analysis for highfrequency seismic energy radiation from the 2011 Mw9.0 off the Pacific coast of Tohoku earthquake, Bull. Seism. Soc. Am., Vol.103, pp.1348-1359, 2013.

27) Kurahashi, S. and Irikura, K.: Short-period source model of the 2011 Mw9.0 off the Pacific coast of Tohoku earthquake, Bull. Seism. Soc. Am., Vol.103, pp.1373-1393, 2013.

28) Nozu, A.: A super asperity model for the 2011 off the Pacific coast of Tohoku earthquake, Journal of Japan Assoc. Earthq. Eng., Vol.12, pp.21-40, 2012.

29) Koper, K.D., Hutko, A.R., Lay, T., Ammon, C.J. and Kanamori, H.: Frequency-dependent rupture process of the 2011 Mw9.0 Tohoku Earthquake: Comparison of short-period $\mathrm{P}$ wave backprojection images and broadband seismic rupture models, Earth Planets Space, Vol.63, pp.599-602, 2011.

30) Ide, S., Baltay, A. and Beroza, G.C.: Shallow dynamic overshoot and energetic deep rupture in the $2011 \mathrm{Mw} 9.0$ Tohoku-Oki earthquake, Science, Vol.332, pp.1426-1429, 2011.

31) Lay, T., Kanamori, H., Ammon, C.J., Koper, K.D., Hutko, A.R., Ye, L., Yue, H. and Rushing, T.M.: Depth-varying rupture properties of subduction zone 
megathrust faults, J. Geophys. Res., Vol.117, B04311, 2012.

32) Yagi, Y., Nakao, A. and Kasahara, A.: Smooth and rapid slip near the Japan Trench during the 2011 Tohoku-oki earthquake revealed by a hybrid backprojection method, Earth Planet. Sci. Lett., Vol.355356, pp.94-101, 2012.

33) Aochi, H. and Ide, S.: Conceptual multi-scale dynamic rupture model for the 2011 off the Pacific coast of Tohoku earthquake, Earth Planets Space, Vol.63, pp.761-765, 2011.

34) Duan, B.: Dynamic rupture of the 2011 Mw9.0 Tohoku-oki earthquake: roles of a possible subducting seamount, J. Geophys. Res., Vol.117, B05311, 2012.

35) Hunag, Y., Meng, L. and Ampuero, J.P.: A dynamic model of the frequency-dependent rupture process of the 2011 Tohoku-oki earthquake, Earth Planets Space, Vol.64, pp.1061-1066, 2012.

36) Goto, H., Yamamoto, Y. and Kita, S.: Dynamic rupture simulation of the 2011 off the Pacific coast of Tohoku earthquake: multi-event generation within dozens of seconds, Earth Planets Space, Vol.64, pp.1167-1175, 2012.

37) Kozdon, J.E. and Dunham, E.M.: Rupture to the trench: dynamic rupture simulations of the 11 march 2011 Tohoku earthquake, Bull. Seism. Soc. Am., Vol.103, pp.1275-1289, 2013.

38) National Research Institute for Earth Science and Disaster Prevention: Strong-motion earthquake records in Japan, 2011, Vol.52, http: //www . k-net . bosai . go.jp/KYOUKAN/No52/52index/52indexe.htm, 2013 (access: Aug. 26, 2013).

39) Kaneko, M., Kataoka, S., Nagaya, K. and Matsuoka, K.: Strong motion records from the 2011 off the Pacific coast of Tohoku earthquake, Technical note of National Institute for Land and Infrastructure Management, No.726, National Institute for Land and Infrastructure Management, Ministry of Land, Infrastructure, Transport and Tourism, Japan, http://www.nilim.go . $\mathrm{jp} / \mathrm{lab} / \mathrm{bcg} / \mathrm{siryou} / \mathrm{tnn} / \mathrm{tnn} 0726 . \mathrm{htm}, 2013$ (in Japanese, access: Aug. 26, 2013).

40) Japan Meteorological Business Support Center: Strong ground motion records 2011-2012, DVD, 2013 (in Japanese).

41) Nozu, A. and Wakai, J.: Annual reports on strong motion earthquake records in Japanese ports (2011), Technical Note of the Port and Airport Research Institute, No.1266, Port and Airport Research Institute, Japan, http://www.pari.go.jp/cgi-bin/ search-ja/detail.cgi?id=20130325161220, 2013 (in Japanese with English abstract, access: Aug. 26, 2013).

42) BRI Strong Motion Observation: The 2011 off the Pacific coast of Tohoku Earthquake of March 11, $2011(\mathrm{M}=9.0, \mathrm{~h}=24 \mathrm{~km})$, Building Research Institute, http://smo.kenken.go.jp/smreport/ 201103111446, 2012 (access: Aug. 26, 2013).

43) Hazarika, H., Kasama, K., Suetsugu, D., Kataoka, S. and Yasufuku, N.: Damage to geotechnical structures in waterfront areas of northern Tohoku due to the March 11, 2011 tsunami disaster, Indian Geotech
J., Vol.43, No.2, pp.137-152, 2013.

44) Kataoka, S. and Yamamoto, H.: Amplification factors of ground motion indices in Aomori Prefecture estimated from observed ground motion, Journal of Japan Association for Earthquake Engineering, Vol.7, No.2, pp.110-129, 2007 (in Japanese with English abstract).

45) Yamamoto, H., Saito, M., Ishizawa, T., Ube, Y. and Saito, R.: A ultrahigh density questionnaire seismic intensity survey in the central area of Maesawa town of Oshu city, Iwate Prefecture, of the 2011 off the Pacific coast of Tohoku earthquake and the largest afterschock, Tohoku Journal of Natural Disaster Science, Vol.48, pp.5-10, 2012 (in Japanese).

46) Yamamoto, H., Saito, T., Okawara, M., Ube, Y., Saito, R. Ichinohe, K. and Kikuchi, K.: A ultra high density questionnaire seismic intensity survey in Ichinoseki city, Iwate Prefecture of the 2011 off the Pacific coast of Tohoku Earthquake and the aftershock, Tohoku Journal of Natural Disaster Science, Vol.49, pp.35-40, 2013 (in Japanese).

47) Ohno, S., Motosaka, M., Shibayama, A. and Mitsuji, K.: Strong-motion characteristics in Sendai city during the 2011 Tohoku earthquake, Japan, Proc. of 15 WCEE, Paper No.3631, 2012.

48) Ohno, S., Motosaka, M., Mitsuji, K. and Shibayama, A.: Site response characteristics in Sendai city estimated from acceleration records of the 2011 Tohoku earthquake, Japan, Proc. of the Int'l Symposium on Engineering Lessons Learned from the 2011 Great East Japan Earthquake, Tokyo, pp.395-405, 2012.

49) Goto, H., Morikawa, H. and Kuwata, Y.: Estimation of ground motion at Furukawa gas during 2011 off the Pacific coast of Tohoku earthquake, Journal of Structural Mechanics and Earthquake Engineering A1, JSCE, Vol.68, pp.I_111-118, 2012 (in Japanese with English abstract).

50) Geological Survey of Japan, AIST: Seamless digital geological map of Japan 1:200,000. Feb. 1, 2010 version, Research Information Database DB084, Geological Survey of Japan, National Institute of Advanced Industrial Science and Technology, 2010.

51) Goto, H., Morikawa, H., Inatani, M., Ogura, Y., Tokue, S., Zhang, X., Iwasaki, M., Araki, M., Sawada, S. and Zerva, A.: Very dense seismic array observations in Furukawa district, Japan, Seismological Research Letters, Vol.83, pp.765-774, 2012.

52) Sripunyaphikhup, S., Morikawa, H., Goto, H., Inatani, M., Ogura, Y., Tokue, S., Zhang, X.R., Hamasaki, S., Iwasaki, M., Araki, M. and Sawada S.: Estimation of ground structure using gravity survey method around Furukawa, Japan, where was severely damaged by 2011 Tohoku earthquake, Proc. for 10th Int'l Conf. on Urban Earthquake Engineering (10CUEE), Tokyo, Japan, pp.257-260, 2013.

53) Inatani, M., Goto, H., Morikawa, H., Ogura, Y., Tokue, S., Zhang, X., Iwasaki, M., Araki, M., Sawada, S. and Zerva, A.: Shallow subsurface model at Furukawa district based on very dense seismic array observations, Journal of Structural Mechanics and Earthquake Engineering Al, JSCE, in printing (in Japanese with English abstract).

54) Nakamura, S., Hori, Y. and Atsugase, Y.: Compari- 
son of seismic intensity by questionnaire survey for Koriyama and Sukagawa due to the 2011 off the Pacific coast of Tohoku earthquake of ground properties, Tohoku Journal of Natural Disaster Science, Vol.49, pp.53-56, 2013 (in Japanese).

55) Fujiwara, H. and Midorikawa, N.: Seismic hazard assessment for Japan after the 2011 Tohoku-oki megathrust earthquake (Mw9.0), Proc. of the Int'l Symposium on Engineering Lessons Learned from the 2011 Great East Japan Earthquake, Tokyo, pp.406-417, 2012.

56) Irikura, K. and Kurahashi, S.: Strong ground motions during the 2011 Pacific coast off Tohoku, Japan earthquake, Proc. of the Int'l Symposium on Engineering Lessons Learned from the 2011 Great East Japan Earthquake, Tokyo, pp.9-20, 2012.

57) Nozu, A., Yamada, M., Nagao, T. and Irikura, K.: Generation of strong motion pulses during huge subduction earthquakes and scaling of their generation areas, Journal of Japan Association for Earthquake Engineering, Vol.12, No.4, pp.209-228, 2012 (in Japanese with English abstract).

58) Hata, Y., Takahashi, Y., Goto, H. and Nozu, A.: Seismic waveform evaluation at damage sites of rubber bearings during the 2011 off the Pacific coast of Tohoku earthquake, Journal of Japan Association for Earthquake Engineering, Vol.13, No.3, pp.30-56, 2013 (in Japanese with English abstract).

59) Hata, Y., Nozu, A., Nakamura, S., Ichii, K., Sakai, H. and Maruyama, Y.: Ground motion evaluation at the Rokko bridge for the 2011 off the Pacific coast of Tohoku earthquake, Journal of Japan Association for Earthquake Engineering, Vol.12, No.3, pp.49-52, 2013 (in Japanese with English abstract).

60) Hata, Y., Ichii, K., Tokida, K., Nozu, A., Yokota, S. and Kaneta, K.: Strong motion estimation at the embankment of the Joban expressway damaged by the 2011 off the Pacific coast of Tohoku earthquake and its largest aftershock based on site effect substitution method, Journal of Structural Mechanics and Earthquake Engineering A1, JSCE, Vol.68, No.4, pp.I_315330, 2012 (in Japanese with English abstract).

61) Hata, Y., Kuwata, Y. and Nozu, A.: Seismic waveform evaluation at Naka-river aqueduct site for the 2011 off the Pacific coast of Tohoku earthquake based on the site-effect substitution method, Journal of Japan Association for Earthquake Engineering, Vol.12, No.4, pp.374-393, 2013 (in Japanese with English abstract).

62) National Institute for Land and Infrastructure Management, Ministry of Land, Infrastructure, Transport and Tourism, Japan \& Building Research Institute (BRI), Incorporated Administrative Agency, Japan: Summary of the field survey and research on "the 2011 off the Pacific coast of Tohoku earthquake" (the Great East Japan Earthquake), Technical Note of NILIM, No.647 E BRI Research, Paper No.150, 2011.

63) Okamoto, A., Kuwata, Y. and Saito, S.: Application of new seismic intensity for building damage evaluation to the 2011 off the Pacific coast of Tohoku earthquake, Journal of Institute of Social Safety Science, 2013 (in printing, in Japanese).

64) Nozu, A. and Ichii, K.: "Evidence-based design" Its definition and related problems, Proc. of 13th
Japan Earthquake Engineering Symposium, JAEE, pp.3073-3080, Tsukuba, Japan, 2010 (in Japanese with English abstract).

65) Takahashi, Y. and Goto, H.: Damage of Daiichi Nakasone elevated bridges due to the 2011 off the Pacific coast of Tohoku Earthquake, Proc. of the 14th Symposium on Performance-based Seismic Design Method for Bridges, Tokyo, pp.465-472, 2011 (in Japanese).

66) East Japan Railway Company: The 2011 off the Pacific coast of Tohoku earthquake and railway structure, Special Issue, Structural Engineering Data, No.37, Structure Engineering Center, pp.35-36, 2011 (in Japanese).

67) Takahashi, Y.: Damage of rubber bearings and dampers of bridges in 2011 Great East Japan earthquake, Proc. of the Int'l Symposium on Engineering Lessons Learned from the 2011 Great East Japan Earthquake, Tokyo, pp.1333-1342, 2012.

68) National Institute for Land and Infrastructure Management, Public Works Research Institute: Quick report on damage to infrastructures by the 2011 off the Pacific coast of Tohoku Earthquake, Technical Note of NILIM, No.646 E Technical Note of Public Works Research Institute No.4202, pp.377-462, 2011 (in Japanese with English abstract).

69) Hata, Y., Nozu, A., Nakamura, S., Takahashi, Y. and Goto, H.: Strong motion estimation at the elevated bridges of the Tohoku Shinkansen damaged by the 2011 off the Pacific coast of Tohoku Earthquake based on extended site effects substitution method, Proc. of the Int'l Symposium on Engineering Lessons Learned from the 2011 Great East Japan Earthquake, Tokyo, pp.418-429, 2012.

70) Hata, Y., Takahashi, Y., Goto, H. and Nozu, A.: Strong motion estimation at Iwakiri Railway Bridge for the 2011 off the Pacific coast of Tohoku Earthquake based on a super asperity model considering empirical site amplification and phase effects, Journal of Structural Engineering, JSCE, Vol.59A, pp.383395, 2013 (in Japanese with English abstract).

71) Hata, Y., Nozu, A. and Ichii, K.: A practical method to estimate strong ground motions after an earthquake based on site amplification and phase characteristics, Bull. Seism. Soc. Am., Vol.101, No.2, pp.688-700, 2011.

72) Kaminaka, R., Kuwata, Y. and Takeda, S.: Damage mechanism of the Nakagawa water-pipe bridge during the 2011 Tohoku Earthquake, Journal of Structural Mechanics and Earthquake Engineering A1, JSCE, Vol.69, No.4, pp.I_171-181, 2013 (in Japanese with English abstract).

73) Murao, H., Kamai, T. and Ohta, H.: Slope disaster in urban residential region by earthquake - Take "the 2011 off the Pacific coast of Tohoku earthquake" as an example-, Journal of the Japan Society of Engineering Geology, Vol.53, No.6, pp.292-301, 2013 (in Japanese with English abstract).

74) Kamai, T.: Observations on landslides movements in residual slopes induced by the 2011 off the Pacific coast of Tohoku earthquake, Journal of the Japan Society of Engineering Geology, Vol.53, No.6, pp.282291, 2013 (in Japanese with English abstract).

75) Kamai, T.: Landslides in residential slope induced by 
the 2011 off the Pacific coast of Tohoku earthquake, Journal of Japan Society for Natural Disaster Science, Vol.30, No.2, pp.193-197, 2011 (in Japanese with English abstract).

76) Nakamura, S., Hata, Y., Abe, K., Shinoda, M. and Nozu, A.: Study for clarifying the failure mechanism of reclaimed land at Fukushima City by use of the estimated strong earthquake motion during the 2011 off the Pacific coast of Tohoku earthquake, Proc. of 15th World Conference on Earthquake Engineering, Paper No.1352, 2012.

77) Hata, Y., Kamai., T., Wang, G. and Nozu, A.: Strong motion estimation in Oritate District, Sendai City, for the 2011 off the Pacific coast of Tohoku Earthquake based on extended site effect substitution method, Journal of Structural Mechanics and Earthquake Engineering A1, JSCE, Vol.69, No.4, pp.I_298-310, 2013 (in Japanese with English abstract).

78) Hata, Y., Kamai., T., Nozu, A. and Wang, G.: Strong motion estimation in Midorigaoka, Sendai City, for the 2011 off the Pacific coast of Tohoku earthquake based on extended site effect substitution method, Journal of Structural Mechanics and Earthquake Engineering A1, JSCE, Vol.69, No.2, pp.152-158, 2013 (in Japanese with English abstract).

79) Hata, Y., Kamai, T., Wang, G. and Nozu, A.: Strong motion estimation in Midorigaoka, Shiroishi City, for the 2011 off the Pacific coast of Tohoku earthquake, Annual Meeting Proc. of Japan Landslide Society, Vol.51, No.3-06, pp.111-112, Sapporo, Japan, 2012 (in Japanese with English abstract).

80) Hata, Y., Nakamura, S. and Nozu, A.: Evaluation of the site amplification factor with considerations of soil nonlinearity - Seismic waveform estimation at the embankment in Fukushima City damaged by the 2011 off the Pacific coast of Tohoku earthquake-, Japanese Geotechnical Journal, Vol.7, No.1, pp.139149, 2012 (in Japanese with English abstract).

81) Wang, G., Suemine, A., Hata, Y. and Kamai, T.: On the initiation and movement of Hanokidaira landslide from the 2011 Tohoku earthquake, Japan, Proc. of Int'l Symposium on Earthquake-induced Landslides, pp.367-376, Kiryu, Japan, 2012.

82) Araiba, K., Yoshihara, H., Amano, H., Zama, S., Kozeki, D. and Takanashi, K.: Landslides caused by the 2011 off the Pacific coast of Tohoku earthquake and by the earthquake in Fukushima-ken Hamadori on 11 April 2011, Report of National Research Institute of Fire and Disaster, No.111, pp.7-17, 2011 (in Japanese with English abstract).

83) Kimura, T., Wakai, A. and Higuchi, K.: Analysis of the factors affecting slope failures distribution within Northern Kanto Area due to the East Japan Great earthquake, Proc. of Int'l Symposium on Earthquakeinduced Landslides, pp.547-554, Kiryu, Japan, 2012.

84) Hata, Y., Wang, G., Kamai, T., Sumine, A. and Nozu, A.: Seismic waveform estimation at the Hanokidaira landslide induced by the 2011 off the Pacific coast of Tohoku earthquake based on site effects substitution method, Journal of the Japan Landslide Society, Vol.49, No.3, pp.109-118, 2012 (in Japanese with English abstract).
85) Hata, Y., Wang, G. and Kamai, T.: Evaluation of seismic waveforms at the Kamikamato landslide induced by the 2011 off the Pacific coast of Tohoku earthquake and the 2011 Hamadori Fukushima Prefecture Earthquake based on moderate earthquake observation records, Journal of the Japan Landslide Society, Vol.50, No.5, pp.209-218, 2013 (in Japanese with English abstract).

86) Hata, Y., Wang, G., Nozu, A. and Kamai, T.: Strong motion estimation at the Kanaga Landslide, $\mathrm{Na}$ sukarasuyama City, induced by the 2011 off the Pacific coast of Tohoku earthquake (Mw9.0) based on empirical site amplification and phase effects, Proc. of Int'l Symposium on Earthquake-induced Landslides, pp.661-668, Kiryu, Japan, 2012.

87) Murakami, K. and Tokida, K.: Analytical study on sliding failure occurred at Joban Highway Embankment in 2011 off the Pacific coast of Tohoku earthquake, Proc. of the 1st Int'l Symposium on Earthquake Engineering, pp.133-142, Tokyo, Japan, 2012.

88) Ministry of Land, Infrastructure, Transport and Tourism: Quick report on damage to infrastructures by the 2011 off the Pacific coast of Tohoku earthquake [Road], Technical Note of Sendai Office of Rivers and National Highways, Tohoku Regional Development Bureau, 2011 (in Japanese).

89) Hata, Y., Nozu, A. and Tokida, K.: Ground motion evaluation at the earth banks in Yamamoto Town damaged by the 2011 off the Pacific coast of Tohoku earthquake, Journal of Japan Association for Earthquake Engineering, Vol.13, No.3, pp.56-59, 2013 (in Japanese with English abstract).

90) Charatpangoon, B., Kiyono, J., Furukawa, A. and Mimura, M.: Dynamic behaviors of earth fill dam under the 2011 Tohoku earthquake, Proc. of the 1st Int'l Symposium on Earthquake Engineering, pp.169-176, Tokyo, Japan, 2012.

91) Hata, Y., Nakamura, S. and Nozu, A.: Seismic waveform evaluation at the Fujinuma Dam for the 2011 off the Pacific coast of Tohoku earthquake - Application of site effect substitution method to a huge subduction earthquake-, Journal of Structural Engineering, JSCE, Vol.58A, pp.250-263, 2012 (in Japanese with English abstract).

92) Zheng, Y., Kosa, K. and Sasaki, T.: Tsunami damage analysis for bridges in Shizugawa area, Journal of Structural Engineering, JSCE, Vol.59A, pp.439-449, 2013.

93) Hata, Y., Akiyama, M., Takahashi, Y., Goto, H., Nozu, A. and Kosa, K.: Strong motion estimation in Shizugawa, Minamisanriku Town, for the 2011 off the Pacific coast of Tohoku earthquake based on a super asperity model considering empirical site amplification and phase effects, Journal of Ocean Engineering B3, JSCE, Vol.69, No.2, pp.I_161-166, 2013 (in Japanese with English abstract).

94) Wessel, P. and Smith, W.H.F.: New improved version of the Generic Mapping Tools released, EOS Trans. $A G U$, Vol.79, p.579, 1998.

(Received July 1, 2013) 